\title{
Development of Contextual Based Textbooks on Plant Structure Subjects: Organum Nutritivum Material
}

\author{
Upik Yelianti ${ }^{1, *}$ Pinta Murni ${ }^{2}$, Muswita $^{3}$ \\ ${ }^{123}$ Biology Education, Teacher Training and Education Faculty Universitas Jambi \\ *Corresponding author. Email: upikyelianti@ymail.com
}

\begin{abstract}
Lack of adequate textbooks is a major obstacle for students in learning materials. Often students feel bored, because textbooks that are usually used the pictures of plants that are colourless. The purpose of this research is to develop a textbook that is more attractive and is equipped with pictures of plants that are contextual in nature. This research is an R \& D research with a 4D model with the following stages: Define, Design, Develop, and Disseminate. At the design stage, an analysis of the problems faced by students was carried out, namely the inadequacy of the source books used and the solution was the development of contextual-based textbooks. Then develop it to see the feasibility of the expert appraisal and developmental testing. The results of the validation by content experts in the first stage obtained a score of 65 in the good category. Secondly, it was revised according to the validator's suggestion, then carried out the second stage validation so that the score increased to 79 in the very good category. The results of the validation by media design experts were carried out twice, in stage I with a score of 66 in the good category, then it was revised so that the score increased to 79 in the very good category. For the next stage, small and large group trials will be carried out, then the dissemination stage will be carried out in the following year. In conclusion, the contextual-based Plant Structure textbook is suitable as teaching material for Biology students
\end{abstract}

Keywords: textbook, plant structure, contextual, organum nutritivum.

\section{INTRODUCTION}

Textbooks are something that is very much needed to support learning in primary, secondary school and universities. The textbook is a book that gives instruction in a subject used especially in schools [1]. During the Covid19 pandemic, learning was carried out online, therefore, the existence of representative textbooks was needed. The Plant Structure course is a course that studies the external character of plants, known as plant morphology. Plant morphology is an external structural feature that is well visible to the eye senses, whereas anatomy is the study of microscopic internal characteristics [2] [3]. Plants have very various characteristics and each of these characteristics has its own term in Latin language. The lack of representative textbooks in the Plant Structure course makes students feel bored and bored, making it difficult for students to understand. Textbooks that are commonly used as references in learning plant structure courses present material in small writing and the sample of plants that are colourless. The textbook for the plant structure course being developed is a book that is written in an adequate size so that it is easy to read and is equipped with coloured sample plants that are contextual in nature.

Several studies have been carried out in the development of textbooks as references in learning biology specifically about plant morphology. Shipunov [2] presents a very complete and detailed plant morphological structure and is accompanied by colourful pictures, but does not provide complete and colourful examples of plants. Dengler,[4] examines plant anatomy which is a study of the internal structure or the inside of a plant that can only be seen using a microscope, such as the tissue that makes up leaves, roots and stems.

Hadisunarso [5] has developed a leaf morphology module which aims to provide knowledge about leaf diversity based on morphological characteristics. This module presents material about the parts of a leaf, leaf characteristics, for example: leaf shape (circumscription), leaf tip (apex folii), leaf base (basis folii), leaf edges (margo folii), leaf arrangement (filotaxis), leaf flesh (intervenium), leaf colour, and compound leaves (folium compositum). However, this module also discusses the tissues that make up the leaf 
organs, whereas in fact when we talk about plant morphology it means that the discussion focuses on the external characteristics of the plant.

Tjitrosoepomo [6], has also written a book on Plant Morphology which examines the structure of the external characteristics of plants. The book is written completely, so that it is widely used in various study programs of biology, agricultural science, animal husbandry, pharmacy, environmental science, and others. This plant structure material is the basis for studying of biodiversity of plant and plant taxonomy. However, this book also has a weakness, which is written in a small font size, so it makes the eyes become tired when reading it. In addition, the sample of plants are presented with a colourless image. Therefore, it is necessary to develop the textbooks for the interesting plant structure courses by completing them with real example pictures (contextual), so that students are expected to be more comfortable learning them and provide optimal learning outcomes.

\section{METHODS}

This research is a research development by adopting a Four D (4D) model with 4 stages, namely: D: define, D: design, D: develop, and D; Disseminate [7]. However, for this year the research was limited to the develop stage, while the dissemination stage would be continued in the following year.

At this Define stage, needs analysis was carried out, looking for the root of the problems that occur in learning plant structure courses, concept analysis, syllabus, learning objectives, and analysis of student characteristics. At this stage, it was found that the problems faced by students were the lack of adequate and interesting source books.

The next stage is Design, which is the stage for designing a textbook draft for the contextual-based Plant Structure course. At this stage, the collection of material, pictures of plant leaves in Jambi is carried out. This textbook will also include the Learning Objectives and Competencies to be achieved which are arranged according to the learning outcomes.

The third stage is develop (development): The development stage is the stage to produce the textbook of plant Structure which is carried out in two steps, namely: (1) expert appraisal followed by revision, (2) developmental appraisal. The aim of this development stage is to produce the final form of learning resources after going through revisions based on input from experts /practitioners and trial test.

\section{RESULT AND DISCUSSION}

The development of the textbook of plant structure has been completed using the Four D (4D) model with the following stages: define, design, develop and disseminate. The results of the development of the textbooks of plant structure courses on organum Nutrititivum material for biology education students are presented as follows:

\subsection{Define}

At this stage the main problem found is the lack of variation in textbooks on plant structure courses. Based on the analysis of various books on plant structure, only 1 book can be used as a reference book for plant structure course because it has the complete and detailed content is in accordance with the syllabus. However, the book has weaknesses, among others, namely: it is written in a rather small size, the font size is also small so that it causes the eyes to tire quickly, and the pictures of plants are presented in black and white, so that they are less motivated in studying them. Based on this analysis, a representative teaching material is needed, with photos of plant samples which are generally taken from plants in Jambi and presented in a rather large size, making it easier for students to learn.

\subsection{Design}

At this stage, the collection of material to develop the textbook of plant structure is carried out. At this design stage, designing and making a prototype of textbook for the Plant Structure course is based on data obtained from initial observations. At this stage, several activities have been carried out including:

a. Collecting material from several learning resources.

b. Collecting pictures of sample of plants from Jambi district (contextual)

c. Cover layout design containing: textbook title, writing team or authors, institution (Biology Education Program Study, Teacher Training and Education Faculty, Universitas Jambi, logo, several photos of plants. Fig 1. The cover of textbook of Plant Structure before and after revision as below: 


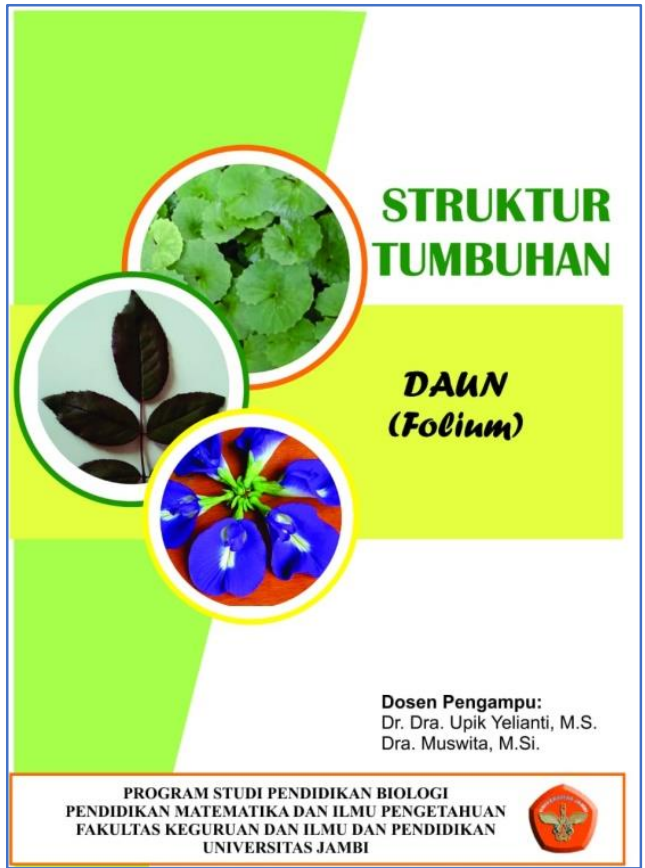

(a)

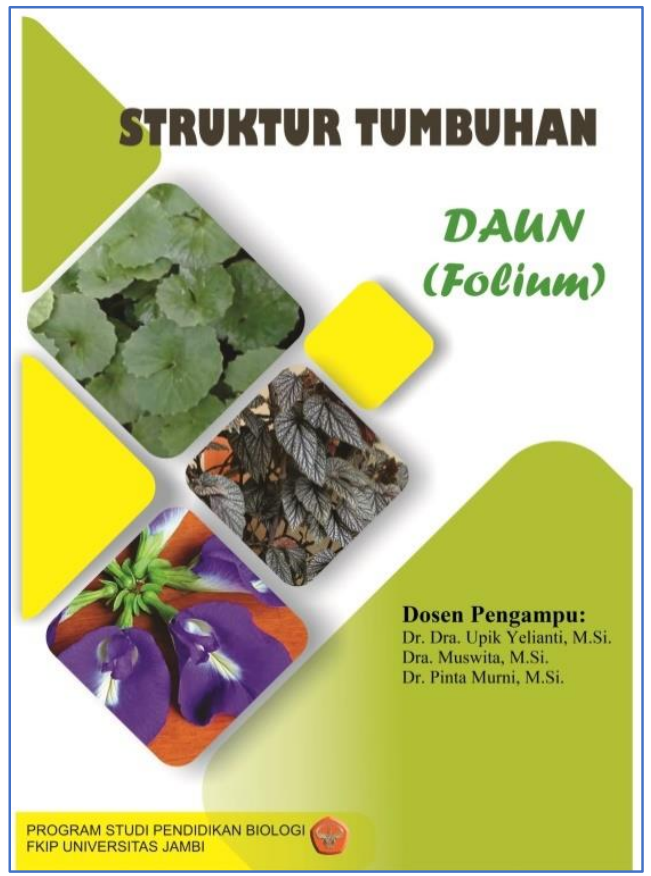

(b)

Figure 1. Cover of textbook of Plant Structure, before revision (a) and after revision (b).

(a)

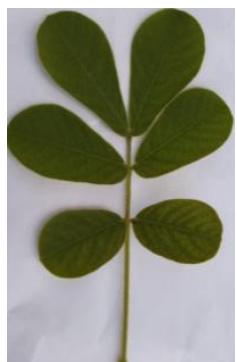

(d) (b)

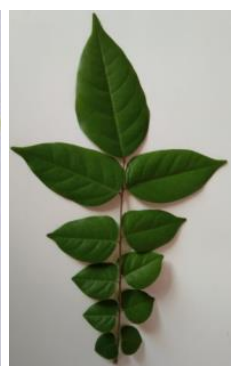

(e) contained in the Plant Structure textbook that illustrate some examples of leaf external characters, such as: triangular leaf shapes, curved leaves, margo folii, even compound leaves (imparipinates), odd compound leaves (abrupte paripinates).
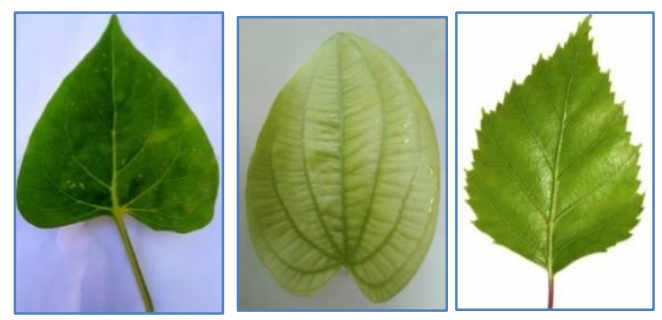

Figure 2. Various single leaves ( $a, b$, and $c$ ) and Compound Leaves (d. Even and e. Odd)

\subsection{Develop}

The product prototype is a textbook for the Plant Structure course that has been developed and validated by material experts and design experts. At this stage, the plant structure textbook has been validated by material experts once with a score about 64 with the good category. Therefore, the textbooks must be revised according to the validator's suggestions.

Table 1. Recapitulation of Plant Structure Textbook Validation Results by Material Experts

\begin{tabular}{|l|l|c|l|c|l|}
\hline \multirow{2}{*}{ No } & \multicolumn{1}{|c|}{ Indicators } & \multicolumn{4}{c|}{ Assessment Score } \\
\cline { 3 - 6 } & \multicolumn{1}{|c|}{ Stage I } & Revision & $\begin{array}{c}\text { Stage } \\
\text { II }\end{array}$ & Revision \\
\hline I. & CONTENT ELIGIBILITY & 3 & appropriate & 4 & $\begin{array}{l}\text { absolutely } \\
\text { appropriate }\end{array}$ \\
\hline 1. & $\begin{array}{l}\text { Conformity with the needs of teaching } \\
\text { materials }\end{array}$ & \multicolumn{3}{|c|}{} \\
\hline
\end{tabular}




\begin{tabular}{|c|c|c|c|c|c|}
\hline 2. & $\begin{array}{l}\text { The information presented follows the } \\
\text { times }\end{array}$ & 4 & $\begin{array}{l}\text { absolutely } \\
\text { appropriate }\end{array}$ & 4 & $\begin{array}{l}\text { absolutely } \\
\text { appropriate }\end{array}$ \\
\hline 3. & $\begin{array}{l}\text { Suitability with the level of student } \\
\text { development }\end{array}$ & 4 & $\begin{array}{l}\text { absolutely } \\
\text { appropriate }\end{array}$ & 4 & $\begin{array}{l}\text { absolutely } \\
\text { appropriate }\end{array}$ \\
\hline 4. & $\begin{array}{l}\text { Appropriateness of concepts (definitions, } \\
\text { laws, principles and mechanisms) }\end{array}$ & 4 & $\begin{array}{l}\text { absolutely } \\
\text { appropriate }\end{array}$ & 4 & $\begin{array}{l}\text { absolutely } \\
\text { appropriate }\end{array}$ \\
\hline 5. & Completeness of information & 3 & Equipped & 3 & appropriate \\
\hline 6. & $\begin{array}{l}\text { Material about skill developers and } \\
\text { achievement abilities }\end{array}$ & 3 & $\begin{array}{l}\text { Develop more } \\
\text { skills }\end{array}$ & 4 & $\begin{array}{l}\text { absolutely } \\
\text { appropriate }\end{array}$ \\
\hline 7. & $\begin{array}{l}\text { Activities in textbooks support } \\
\text { understanding of the material }\end{array}$ & 3 & Added more & 4 & $\begin{array}{l}\text { absolutely } \\
\text { appropriate }\end{array}$ \\
\hline 8. & $\begin{array}{l}\text { Activities in textbooks require } \\
\text { observation of natural phenomena and } \\
\text { objects }\end{array}$ & 3 & appropriate & 3 & Appropriate \\
\hline 9. & Useful for broadening students' insight & 4 & $\begin{array}{l}\text { absolutely } \\
\text { appropriate }\end{array}$ & 4 & $\begin{array}{l}\text { absolutely } \\
\text { appropriate }\end{array}$ \\
\hline II. & LEGIBILITY & & & & \\
\hline 10. & Ease textbook to read and understand & 3 & appropriate & 4 & $\begin{array}{l}\text { absolutely } \\
\text { appropriate }\end{array}$ \\
\hline 11. & $\begin{array}{l}\text { Conformity with Indonesian language } \\
\text { rules }\end{array}$ & 3 & appropriate & 3 & Appropriate \\
\hline 12. & $\begin{array}{l}\text { Utilization of languages effectively and } \\
\text { efficiently }\end{array}$ & 3 & appropriate & 3 & Appropriate \\
\hline 13. & $\begin{array}{l}\text { Clarity of information and easy to } \\
\text { understand students }\end{array}$ & 3 & appropriate & 4 & $\begin{array}{l}\text { absolutely } \\
\text { appropriate }\end{array}$ \\
\hline 14. & Suitability titles and captions on pictures & 4 & $\begin{array}{l}\text { absolutely } \\
\text { appropriate }\end{array}$ & 3 & Appropriate \\
\hline 15. & $\begin{array}{l}\text { Appropriateness of illustrations to clarify } \\
\text { concepts }\end{array}$ & 3 & appropriate & 4 & $\begin{array}{l}\text { absolutely } \\
\text { appropriate }\end{array}$ \\
\hline 16. & The attractiveness of the illustrations & 4 & $\begin{array}{l}\text { absolutely } \\
\text { appropriate }\end{array}$ & 4 & $\begin{array}{l}\text { absolutely } \\
\text { appropriate }\end{array}$ \\
\hline 17. & $\begin{array}{l}\text { The suitability of the use of the term with } \\
\text { the concept being studied }\end{array}$ & 3 & appropriate & 4 & $\begin{array}{l}\text { absolutely } \\
\text { appropriate }\end{array}$ \\
\hline 18. & $\begin{array}{l}\text { Appropriate explanations for difficult and } \\
\text { unusual terms }\end{array}$ & 3 & appropriate & 3 & Appropriate \\
\hline III & ORGANIZING AND PRESENTING & & & & \\
\hline 19. & $\begin{array}{l}\text { The accuracy of the chapter title with the } \\
\text { material content. }\end{array}$ & 3 & appropriate & 3 & Appropriate \\
\hline 20 & $\begin{array}{l}\text { Numbering between chapters were } \\
\text { consistent and hierarchical }\end{array}$ & 3 & appropriate & 3 & Appropriate \\
\hline 21. & $\begin{array}{l}\text { Organizing the material describes the } \\
\text { whole material }\end{array}$ & 2 & Fix as suggested & 3 & Appropriate \\
\hline 22. & The material is arranged systematically & 3 & appropriate & 3 & Appropriate \\
\hline & The total score & 65 & Good & 79 & Very Good \\
\hline & Suggestions / Comments & \multicolumn{2}{|c|}{$\begin{array}{l}\text { The textbook is classified } \\
\text { as Good, but it is } \\
\text { suggested to be improved } \\
\text { according to the } \\
\text { suggestions }\end{array}$} & \multicolumn{2}{|c|}{ It's worth testing it } \\
\hline
\end{tabular}

Based on Table 1, it can be seen that the results of stage I validation from material experts obtained a score of 65 in the good category. Components that are still not good enough to be repaired. The descriptor components that must be improved include: this textbook has not stimulated students to achieve, the activities in this book do not require students to observe plant examples in their surroundings, the suitability of illustrations / pictures to explain the concept being studied is still there are less clear pictures of the characters shown, for example the presence of ochrea and stipules on the leaves. Then the components of the assignments given to students are not 
yet visible and will be completed, and the component of the evaluation questions also does not exist and will be completed. After being corrected and equipped in accordance with the validator's suggestions, it will be followed by stage II validation, the score is 79 in the very good category. After the validation stage is completed, it is continued with the validation of the Plant Structure textbook media design expert.

The results of the validation of the media design expert were also carried out twice. The results of the phase I validation obtained a score of 66 in the good category. Furthermore, the textbook is revised according to the validator's suggestions, such as improving the format to make it clearer, clarifying the word construct and detailing it, adding material that draws student competency improvement, and making space for material summaries. Then the stage II validation was carried out again and obtained a score of: 79 in the very good category. Recapitulation of validation results by Media design experts in the form of Plant Structure textbooks is presented in Table 2. as below:

Table 2. Recapitulation of Plant Structure Textbook Validation Results by Design Media Experts

\begin{tabular}{|c|c|c|c|c|c|}
\hline \multirow[b]{2}{*}{ No } & \multirow[b]{2}{*}{ Indicators } & \multicolumn{4}{|c|}{ Assessment Score } \\
\hline & & $\begin{array}{l}\text { Stage } \\
\text { I }\end{array}$ & Revision & $\begin{array}{l}\text { Stage } \\
\text { II }\end{array}$ & Revision \\
\hline I. & \multicolumn{5}{|l|}{ TEACHING BOOK FORMAT } \\
\hline 1. & $\begin{array}{l}\text { The book title is clear, describes the } \\
\text { content, and is easy to understand }\end{array}$ & 2 & Clear format & 3 & Good \\
\hline 2. & $\begin{array}{l}\text { The material is described and explained in } \\
\text { detail }\end{array}$ & 3 & $\begin{array}{l}\text { The word } \\
\text { construct is } \\
\text { clarified }\end{array}$ & 4 & Very Good \\
\hline 3. & The information provided is complete & 3 & $\begin{array}{l}\text { Add supporting } \\
\text { references }\end{array}$ & 4 & Very Good \\
\hline 4. & $\begin{array}{l}\text { There are a number of suggestions for } \\
\text { students in order to improve their } \\
\text { competence }\end{array}$ & 2 & Add competencies & 3 & Good \\
\hline 5 . & contains a summary of the material & 2 & $\begin{array}{l}\text { Create space for a } \\
\text { summary of the } \\
\text { material }\end{array}$ & 3 & Good \\
\hline II. & \multicolumn{5}{|l|}{ LINGUISTIC AND LEGIBILITY } \\
\hline 6. & $\begin{array}{l}\text { Utilization of languages effectively and } \\
\text { efficiently }\end{array}$ & 3 & Good & 3 & Good \\
\hline 7. & $\begin{array}{l}\text { Conformity with Indonesian language } \\
\text { rules }\end{array}$ & 3 & Good & 4 & Very Good \\
\hline 8. & Easiness to read and understand & 2 & $\begin{array}{l}\text { Latin term } \\
\text { corrections }\end{array}$ & 4 & Very Good \\
\hline 9. & $\begin{array}{l}\text { Suitability notation, symbols and units } \\
\text { used by the international system }\end{array}$ & 2 & $\begin{array}{l}\text { Make footnotes } \\
\text { on important } \\
\text { terms }\end{array}$ & 3 & Good \\
\hline 10. & $\begin{array}{l}\text { Appropriate explanations for difficult and } \\
\text { unusual terms }\end{array}$ & 3 & Good & 3 & Good \\
\hline 11. & $\begin{array}{l}\text { The suitability of the use of the term with } \\
\text { the concept being studied }\end{array}$ & 3 & Good & 4 & Very Good \\
\hline 12. & Clarity of information & 3 & Good & 4 & Very Good \\
\hline \multicolumn{6}{|c|}{ III. PRESENTATION } \\
\hline 13. & Providing a stimulus & 2 & $\begin{array}{l}\text { Add space for } \\
\text { motivation }\end{array}$ & 3 & Good \\
\hline 14. & $\begin{array}{l}\text { Conformity with the presentation of a } \\
\text { systematic and logical rules }\end{array}$ & 3 & Good & 3 & Good \\
\hline 15. & $\begin{array}{l}\text { The existence of providing motivation } \\
\text { and interesting information }\end{array}$ & 2 & Add & 3 & Good \\
\hline IV. & \multicolumn{5}{|l|}{ GRAPICHS } \\
\hline 16. & Attractive display design & 3 & Good & 4 & Very Good \\
\hline 17 & $\begin{array}{l}\text { The use of fonts, type, and size } \\
\text { appropriate article }\end{array}$ & 3 & Good & 4 & Very Good \\
\hline 18. & Interesting illustrations and pictures & 3 & Good & 4 & Very Good \\
\hline
\end{tabular}




\begin{tabular}{|l|l|l|l|l|l|}
\hline 19. & Suitability titles and captions on pictures & 3 & Good & 4 & Very Good \\
\hline 20. & $\begin{array}{l}\text { Appropriateness of illustrations / pictures } \\
\text { to clarify concepts }\end{array}$ & 3 & Good & 4 & Very Good \\
\hline 21. & $\begin{array}{l}\text { Placement of titles, subtitles, illustrations } \\
\text { and captions does not interfere with } \\
\text { understanding }\end{array}$ & 3 & Good & 4 & Very Good \\
\hline 22 & Good Layout & 3 & Good & 4 & Very Good \\
\hline & Score / Category & 69 & Good & 79 & Very Good \\
\hline & Suggestions / Comments & $\begin{array}{l}\text { Fix it according to the } \\
\text { suggestions }\end{array}$ & $\begin{array}{l}\text { The product is feasible to } \\
\text { be tested on Biology } \\
\text { Education students }\end{array}$ \\
\hline
\end{tabular}

Based on Table 2, it can be seen that an increase in the score obtained from validation by media design experts, in stage I obtained a score of 66 in the good category then improvements are made according to the suggestions, so that the score increases to 79 in stage II with the very good category. Furthermore, trials will be carried out on Biology Education Study Program students in the even semester of the 2020/2021 academic year, because the Plant Structure course is offered in that semester, then continued with ISBN management and dissemination to large groups.

\section{CONCLUSION AND SUGESSION}

In conclusion, research on the development of textbooks in plant structure courses has been carried out using the Four D (4D) model with 4 stages: D (Define), $\mathrm{D}$ (Design), D (Develop), and D (Disseminate). However, at this time this research activity was only at the Develop stage. The Plant Structure Textbook has been validated by material experts and media design experts and has been declared worthy of being tested on Biology Education study program students of the Faculty of Teacher Training and Education, Jambi University in the even semester of 2020/2021.

Based on the results of the study, it is recommended to conduct trials in small and large groups and to test the effectiveness of the textbooks that have been developed. Henceforth, it is hoped that the Plant Structure textbook on the Organum Nutritivum material can be used in learning in the Biological Education study program and continued with small group and large group trials. In the end, after the trial and receiving suggestions and improvements from users (students), the ISBN will be taken care of and the Dissemination stage will be carried out. Furthermore, in order to continue the development of textbooks on Organum Reproductivum material so that the plant structure course material is complete.

Acknowledments: thank you very much to Rector Universitas Jambi for funding this research and also to the head of research institution Universitas Jambi.

\section{REFERENCES}

[1] J. Crowther. 1995. Oxford Advanced Learner Dictionary. New York: Oxford University Press

[2] A. Shipunov. 2020. Introduction to Botany. January 20, 2020 version. 192 pp. URL: http://ashipunov.info/shipunov/school/biol_154/

[3] D. R. Kaplan. 2001. The science of Plant Morphology: Defenition, History, and Role in Modern Biology. American Journal of Botany 88(10): 1711-1741. Department of Plant and Microbial Biology, University of California, Berkeley, California 94720-3102 USA

[4] N. G. Dengler. 2002. An Integral Part of Botany. American Journal of Botany, 89 (2) : 369-374.

[5] Hadisunarso, (2013). Morfologi Tumbuhan. In: Morfologi Daun. Universitas Terbuka, Jakarta, pp. 1-61. ISBN 9796897946

[6] G. Tjitrosoepomo. 2001. Morfologi Tumbuhan. Cetakan ke 13 Maret 2001. Gadjah Mada University Press. Yogyakarta.

[7] S. Thiagarajan, D. S. Semmel, \& M. I. Semmel. 1974. Instructional Development for Training Teachers of Expectional Children. Minneapolis, Minnesota: Leadership Training Institute/Special Education, University of Minnesota. 